\title{
農村地域における個人・世帯・イ工の役割分担とその継承方法に関する研究 THE SHARE OF ROLES AND THE WAY OF SUCCESSION TO THEM FROM THE VIEWPOINT OF INDIVIDUAL, A COUPLE, A HOUSEHOLD IN A RURAL AREA
}

\author{
藍澤 宏*, 鈴木 麻衣子**, 斎尾直子*** \\ Hiroshi AIZAWA, Maiko SUZUKI and Naoko SAIO
}

\begin{abstract}
This study researches extended families as the main object and suggests the condition of succeeding to the household and community and the condition of securing one's identity.

The first we grasp the situation of self-government in a rural area and the share of roles in a household from the viewpoint of individual, a couple, a household and a community, the second we show the significance of social system and the prospect of society.

For the progress of society in a rural area, it is necessary to educate the successor and to secure one's identity in a household and social system.
\end{abstract}

Key words : community, extended family, a couple, individual, share of roles, succession to the roles, 地域社会, 払大家族, 世帯, 個人, 役割分担, 役割継承,

\section{1 . 研究の背景と目的}

従来の農村での暮らしには, 生産活動を効率的に進める上での相 互扶助が行われ，それを基盤として暮らしを維持していく生活互助 が成立し, 一集団として共生していくための役割や人間関係が存在 してきた。それら生産・生活互助は, 地域社会を維持し, 継承して いくための社会のしくみとして受け継がれ，それに従って道路等の 生活環境の管理, 集落自治や伝統行事が行われてきた。地域の社会 活動には主にイさ梁を箪位として参画し、イ工同士の連帯が重視され た。しかし, 近年は農業経営の多様化により生産互助の関係は崩れ, また少子高齢化に加えて若者の流出が進み, 農業の存続のみならず, これまで生活互助としてイエが果たしてきた役割が次世代へ継承さ れず，地域運営の形骸化，地縁関係の希薄化等が生じている。これ により, イエを基盤とした地域社会そのものの存続が危ぶまれ, 既 存の地域社会のしくみが社会変化に対応しきれていない状況にある。 一方，新たな暮らしとして，イエを単位とした地域運営に世帯を 単位とした社会参画がみられ始め, また生涯学習等の個人を対象と した活動支援も図られ，個人及び世帯がイエの枠を超え主体性を持 つて参加できる場と機会が展開しつつある。しかしながら，依然と して各人の参加形態は，イエの代表・仕事といったイエを基盤とし た役割に囚われ，特に農村女性には日常の農作業, 家事, 子育てと
いった時間的制約や親・子世帯間の立場による制約がみられ，個人・ 世帯としての活動参加を支援していく体制には十分に至っていない。

このように, イエを単位とした従来型の農村社会のしくみが変容 する一方, 個人の関心の多様化が進む現状において, 今後地域社会 を維持・継承していくためには，従来のしくみを現代に適応させる と共に, 世帯並びに個人を主体とした社会参画を推進することが重 要となる。既往研究としては, 主に社会学分野において, 個人，イ 工, 社会集団の各視点から捉えた地域社会における生活・行動様式 が解明され，建築学分野においては生活・経済の両側面から生活環 境整備に関する今後の計画課題が提示されているが，イエを構成す る世帯に着目した生活・行動様式の検証，また各視点の連関とその

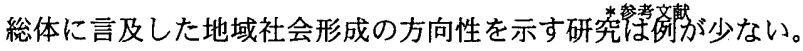

本研究では, 個人・世帯・イエ・地域社会における役割内容と分 担・継承の方法, 及び各人の主体性を把握し，地域社会のしくみの 要素として，イエ・地域社会を維持・継承し得る条件, 及び各人の 主体性を確保し得る条件を明らかにすることを目的とする。

\section{2. 研究の方法}

本稿では，イエ・地域社会における役割分担とその継承の方法を 几しくみ」として捉え, 【地域社会を運営していくしくみ】, 及び地 域社会の構成単位であるイエに関する【地域社会を支えるイエ内部
* 東京工業大学文教施設研究開発センター 教授・工博

** 東京工業大学大学院 大学院生・修士(工学)

*** 東京工業大学文教施設研究開発センタ一 助手・博士 (工学)
Prof., Research and Development Center for Educational Facilities, Tokyo Institute of Technology, Dr. Eng.

Graduate Student, Tokyo Institute of Technology, M. Eng.

Research Assoc., Research and Development Center for Educational Facilities, Tokyo Institute of Technology, Dr. Eng. 
のしくみ〕の 2 つの側面からみていく(図 1)。また, イエ内部の親・ 子世帯間の関係を把握するために抬大家族（直系家族及び複合家族） を主対象とした。第一の『地域社会を運営していくしくみ】につい て,個人単位に [誰が]何の[役割]を担っているのかを把握する。具 体的な社会活動の内容を,生活分野の(1)自治を担う地域組織活動と (2)集団としての世代別組織活動，また生産分野の(基篮となる生産 組織活動と(4)農協組織活動, さらに個人単位の活動である(5)次世代 の育成を図る組織活動と(6)個人の能力向上を目的とする組織活動の 6 分野として捉える。第二に，イエの構成要素である世帯及び個人 を単位として，【地域社会を支えるイエ内部のしくみ】をi）日常生 活における役割分担の方法と ii ) 役割邆承の方法の二点から, 個人 ・ 世帯・イエと地域社会との関係を捉える。具体的には，イエ内の日 常生活においてi）[誰が]何の[役割]を担い，またii）（いつ]何の [役割]を綵承しているのか，その内容を把握する。第三に，地域社 会のしくみを通じて地域運営に対する役割認識を高めた経唋及び地 域社会の一員として次世代への期待内容を個人単位に把握し, 今後 の社会参画への方向とその内容を明らかにする。

以上のことから, 現代社会にみられるイエ・地域社会の維持・䌑 承に関するしくみの内容を把握し，その意義を明らかにすると共に 問題・課題点を抽出し, しくみの今後の有効利用と応用の方法, ま た社会背景に応じた再檴築を提示する。調篔対象地については, 地 域固有性を考虑し, 都市化の進む「都市近郊 A」, 及び交流の域が限 られている茰村の原空間としての「離島 B」, さらに現代の典型的な 農村の「中山間 $\mathrm{C} 」$ から 1 地区づつ抽出し, アンケート及びヒアリ ング調㚗をもとに比較分析を行った。調㚗概要は表 1 に示す。

\begin{tabular}{|c|c|}
\hline 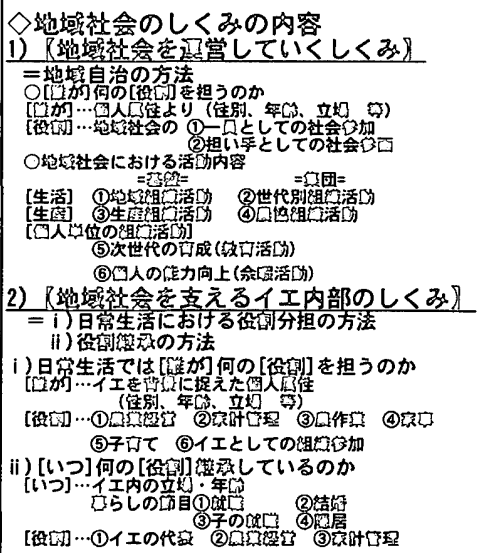 & 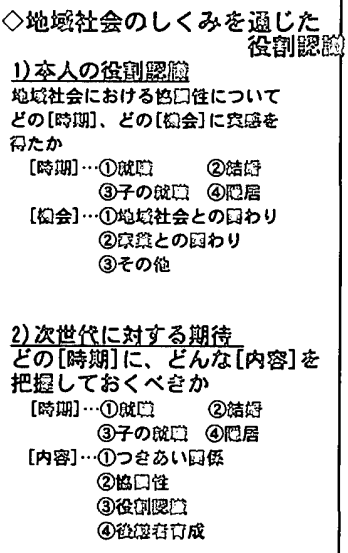 \\
\hline
\end{tabular}

图 1 㽖究の方济

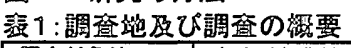

\begin{tabular}{|c|c|c|c|}
\hline 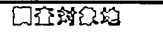 & 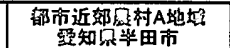 & 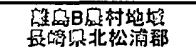 & 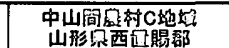 \\
\hline 同聕 & \multicolumn{3}{|c|}{ 南町对鲎位 } \\
\hline 目足程の特解 & 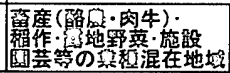 & 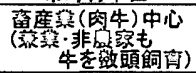 & 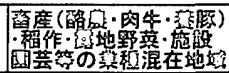 \\
\hline \multicolumn{4}{|l|}{ アンケートロ高 } \\
\hline 四布日 & $1998 / 10 / 20$ & $1998 / 11 / 8$ & $1999 / 1 / 21$ \\
\hline 回顸旦 & $1998 / 10 / 28$ & $1998 / 11 / 20$ & $1999 / 2 / 5$ \\
\hline <宝施票〉 & \multicolumn{3}{|c|}{ 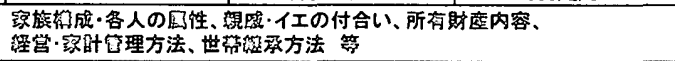 } \\
\hline 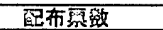 & 40 鼠 & $70 \sqrt{9}$ & 25 每 \\
\hline 亩勃原致 & 295 & 445 & $1 8 \longdiv { 2 }$ \\
\hline 〈蔨人奥〉 & \multicolumn{3}{|c|}{ 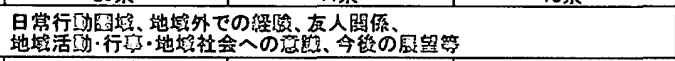 } \\
\hline 基布而致 & 1603 & 280 照 & 100沓 \\
\hline 亩新页政 & 899 & 969 & 62星 \\
\hline ヒフリンク゚ロ弪 & \multicolumn{3}{|c|}{ 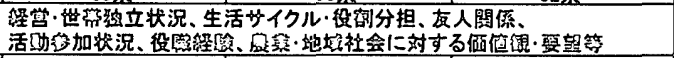 } \\
\hline 般登日 & $1998 / 9 / 29 \cdot 30$ & $1998 / 11 / 3 \sim 6$ & $1999 / 1 / 21 \sim 23$ \\
\hline ヒアリング钎 & $10 \sqrt{2}$ & 10,57 & 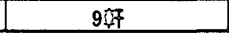 \\
\hline
\end{tabular}

\section{3.绝䄈往会を通営していくしくみ}

『地域社会を運営していくしくみ】の内容を把握するために, 個 人を単位として活動内容 6 分野 21 項目から活動参加状況を把握し, 地域運営への関わり方にみられる特徵を明らかにする（図 2)。

活動参加状況の埋的な特徵として, 老人会や区・班会といった地 縁による従来からの活動への参加が最も多く, 以下畜産部会といっ た生産組織活動に続き, 趣味活動への参加も多くみられ, 身近な地 域を基点に幅広い社会参加の場が広がりつつある傾向がみられる。 また各活動の特徵として, 活動内容によって参加者の内訳が男女別 あるいは性別を問わないものとが存在し，活動目的として男性の方 が運営・管理に直接関わるものが多く，女性はそれらの竄方役もし くは趣哧活動等の個人の楽しみを追求した活動が多い傾向にある。 立場別の特徵として, 男女共に子世帯は教育活動も多く, 親世帯は 老人会への参加が増える。年代別では，20 代では子供会・青年会が 主となり，30 代になると活動内容が增え始め，40 代では，区・班 会といった地域運営の活動もみられる。50 代になると地縁もしくは 社緣による活動に集中し, 60 代以降は老人会への参加が多くなって いく。また地域別では，どの地域においても区・班会といった地域 運営への参加は多くあげられているが, 都市近郊 A は畜産部会とい った社緑による活動に櫝極的である一方, 離島 B では地縁による活 動に偏っており, 両地域共に全体としては活動参加が少ない。他方, 中山間 C では他地域と比べて PTA や子供会世話役といった教育活 動, 趣味活動にも積極的に参加している特徵が得られた。

次に, 各人の活動参加状況の質を活動内容の多様性と主体性から 捉え，その特徵を明らかにするために, 活動内容 21 指標を用い 1

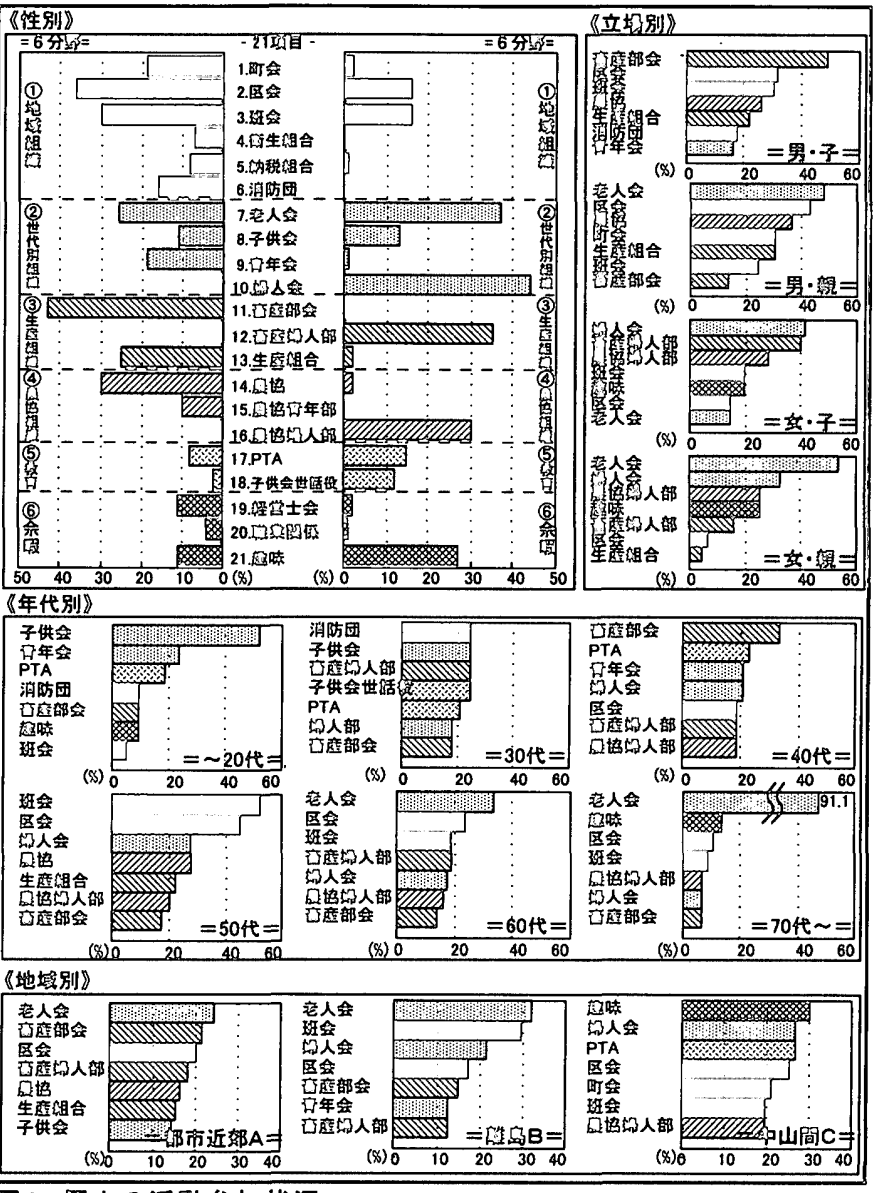

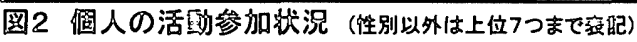


個人を 1 サンプルとして，参加している活動の組み合わせから個人 を数量化 III 類分析で得点值化し, 各人の得点值をクラスター分析ウ オード法により，個人を $\mathrm{A} 1$ A7 の 7 つに分類した(図 3,4,5)。I 軸 は十側に子供会, 青年会, PTA, 一側には老人会が付置する年齢軸,

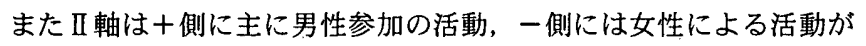
付置する性別軸として捉えられ，I－II 軸より性別・年代の 2 つの 属性に規定された活動参加形態があることが求められた。また軸 は，一側に地域運営を目的とした地域組織分野の活動が偏り，十側 に青年会, 消防団等の個人としての参加がみられる活動が捉えられ る。これにより，I－而軸からは世代間による活動内容の相違が得 られ, 経験則として 1)役割遂行型と 2)余暇充実型の 2 つの構成軸が 求められた。

男性の場合, 活動参加形態は年代に応じて細かく設定されるが, 女性の場合, 婦人活動を中心とした A1 が主に広がる(図 6)。立場別 では, 男性の子世帯が地縁に関係する A2, A3, もしくは社縁活動 中心の $\mathrm{A} 5$ がみられ，親世帯になると地域運営を担っている $\mathrm{A} 2$ と 老人会の参加がみられる $\mathrm{A} 4, \mathrm{~A} 6$ になる。また女性の子世帯は婦人 組織中心の $\mathrm{A} 1$ にほぼ偏り, 親世帯になると $\mathrm{A} 1$ に加えて老人会・ 趣味活動へ参加する A4, A7 がみられる。地域運営中心の A2 につ いては, $50 \cdot 60$ 代を中心とし, 男性だけではなく新たな傾向として 女性も A2 に属する人が認められた。また地域別に親・子世帯間の 特徵をみると, 都市近郊 $\mathrm{A}$ の子世帯男性は $\mathrm{A} 5$ が多くみられ社縁関 係が強く, 女性は婦人活動中心の $\mathrm{A} 1$ を主とし, 地域運営に直接関 わることは少ない。また地域運営中心の $\mathrm{A} 2$ に属する人は, 親子世 帯の男性どちらにもみられる。離島 B は全体として地縁による活動
に偏っている。地域運営中心の A2 は主に子世帯の男女で構成され， 親世帯になるとほぼ A4 の老人会への参加になり，地域社会の担い 手は子世帯中心となっている。中山間 $\mathrm{C}$ も，全体として地縁による 活動への参加が多くみられるが, 男性の子世帯は A2,A3 が主にみら れ，親世帯は地域運営中心の A2 に多く属している。女性は親・子 世帯共に婦人活動中心の $\mathrm{A} 1$ に属しており，特に子世帯には $\mathrm{A} 2$ に 属する人もややみられ，活動の取り組みに積極的な層と捉えられる。

このように，地域社会への関わり方は性別・年代に規定され，地 域社会運営の担い手は 50 代前後の層となるしくみが明らかとなっ た。また地域運営の担い手層は, 特に親・子世帯のどちらがイエの 代表となるかについて，地域固有のしくみが存在することが求めら れた。依然として地域運営は男性による傾向があるが，女性 50 代 の参画がみられたことは, 新たな役割分担の方法として捉えられる。

\section{4 . 地域社会を支えるイエ内部のしくみ}

\section{i ) 日常生活における役割分担の方法}

【地域社会を支えるイエ内部のしくみ】について典型的な家族の i ) 日常生活における役割分担の方法を捉える。まず，有意抽出によ る典型家族のヒアリング調查から得られた各地域の日常生活の過ご し方について，概要とその特徵を示す(図 7)。

都市近郊 A の拡大家族の住まい方は，主に《親子完全同居型》で ある。イエの代表はあくまで男性中心であり，親・子世帯の男女と もに農作業にたずさわるイエが多く，親子・夫婦間の依存関係がみ られる。総じて，普段の行動圈域は職業を通じた集落内での活動を 中心とし，家業中心の生活となる傾向にある。離島 B の住まい方に は《同一敷地内別棟型》がみられ，そこでは親は隱居し，子世帯が
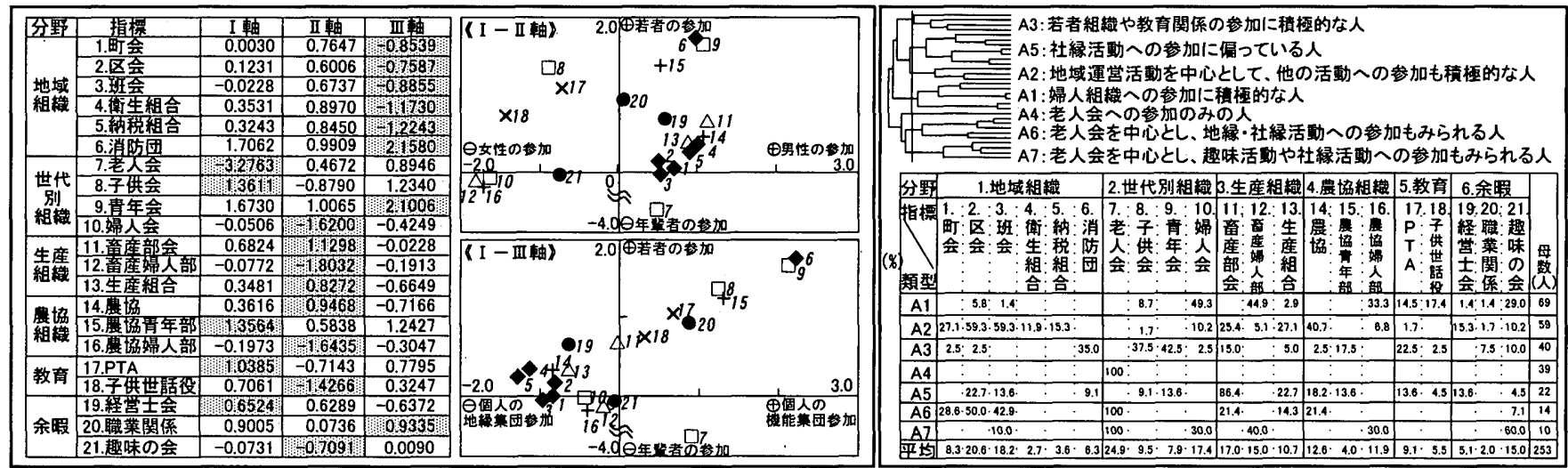

図3 活動㐱加状況に関する個人の固有ベクトルとカテゴリープロット図

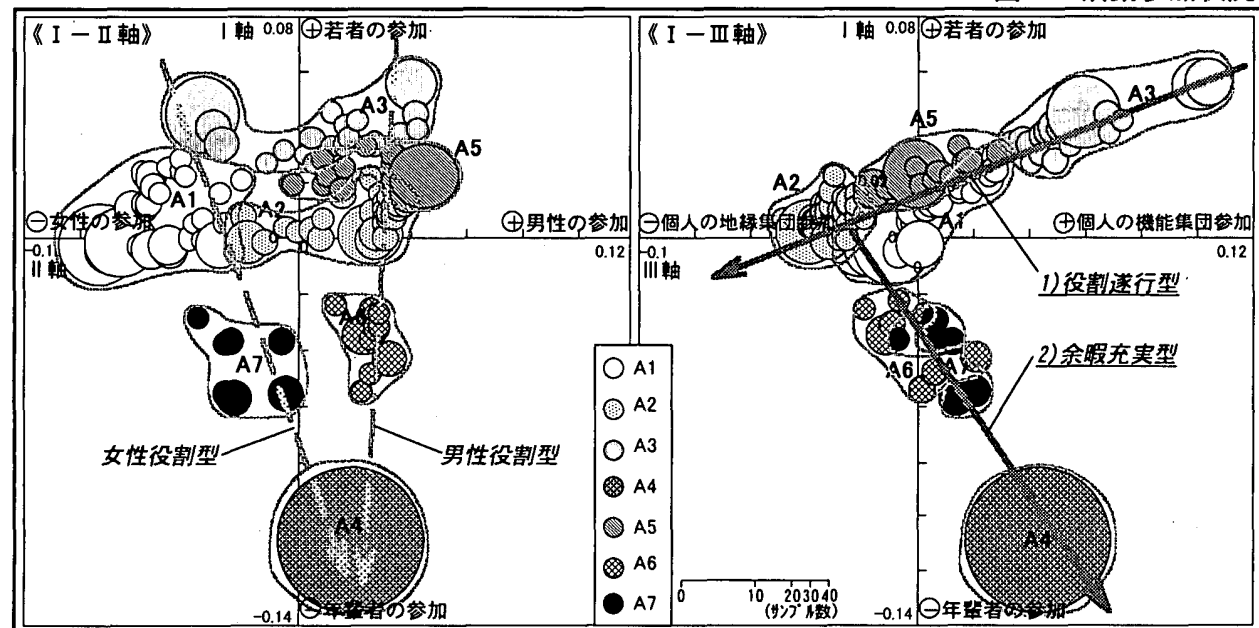

図5 活動参加状況に関する個人のサンプルプロットと類型図

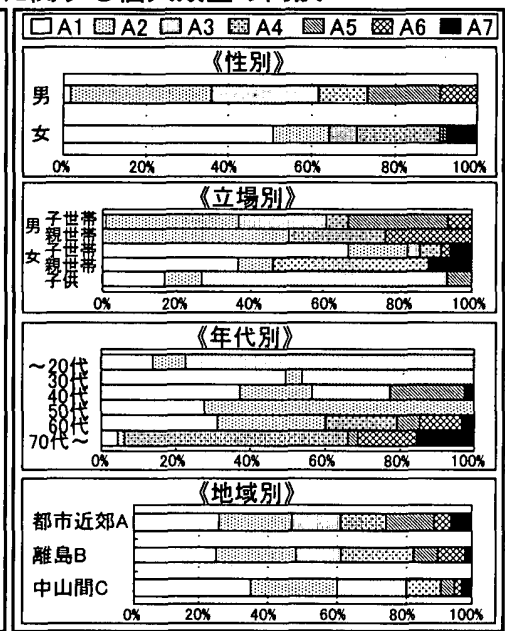

图 6 個人類型の属性別割合 
イエのすべての役割を任され，親子世帯が互いに独立した夫婦単位 の生活を送る。地域での活動は，組織に参加するというよりも，近 陊の友人と自主的な集まりを持っており，立地条件もあいまって， 主に地縁を基盤とした生活となる。中山間 C の拡大家族の住まい方 は，主に《親子完全同居型》である。親世帯の多くは農業経営から 身を引き，子世帯が担っている。また，女性も男性と対等に経営に たずさわったり，地域運営に関わっていたりと積極的に参加してい る人がみられ，そのようなイエでは家事・子育てに関して嫁と姑が 分担・協力をしている場合が多い。イエでの役割を，夫婦単位で行 うことと親子協力して行うことを明確に区分し，親子世帯は一つの イエに住みながらも，互いの距離を保っている。立地上，普段の行 動圈域は町内を主としているが，趣味活動への参加も活発であり， 幅広い活動参加がみられる。

以上のことを踏まえて, 次に集落外での生活内容について, イエ。 地域社会での個人の役割と役割以外の楽しみとしての活動を 6 項目 に設定し，個人を単位として行動圈域を踏まえた生活内容に関する 特徵を明らかにする(図 8)。

珄別にみると,個人の楽しみに関しては男女を問わずみられるが， 男性は, 仕事, 地縁組織参加等のイエ外での活動を主とし, 女性は 家事, 家族の楽しみ, 里帰り等の血緑を中心とした生活を送る傾向 にある。また立場別では，男性の子世帯は仕事中心の生活，親世帯 は地緑組織への会合がそれに加わる。一方女性の子世帯は，女性と してみられた特徵と変わらないが, 親世帯になると個人の楽しみが 増加している。年代別では加齢にともない, $10 \cdot 20$ 代では個人的な 楽しみ， 30 代頃から仕事や家族，地域運営へと変化し， 60 代以降

\begin{tabular}{|c|c|c|c|}
\hline 站站 & 解市近却A & 口马 & 中山間 C \\
\hline $\begin{array}{c}\text { 住まい方 } \\
\text { 世 } \\
\text { 世需間の明係 }\end{array}$ & 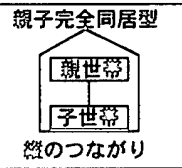 & 互いに & 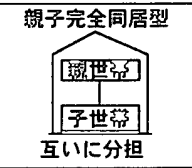 \\
\hline 生活 & 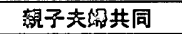 & 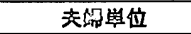 & 親子分担・旿力 \\
\hline 自筑经学 & 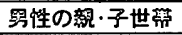 & 子世管塄性中心 & 子世管专缲で㴔力 \\
\hline 家甜管理 & 餎 & 世茾ことに女往加担う & 䗆 \\
\hline 血作瑩 & 視子去缲共同 & 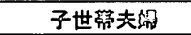 & 子世第文缉 \\
\hline 实可 & 综站一暂卫は別 & 世消ことに女性が担う & 毁姑分担 \\
\hline 五児 & 主に檫 & 慗 & 蜿蛄分担 \\
\hline 地域组缐得加 & 男链 & 子世留の男推 & 䋩世茾の男社 \\
\hline 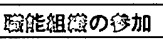 & 䂓·子世带 & 子世篦 & 子世滆 \\
\hline 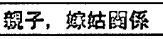 & 倿存时係 & 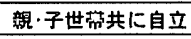 & 紫子の明酎な役河分担 \\
\hline 女锥の立垊 & 政方 & 妨 & 团女対第 \\
\hline 人間榎係 & 社踝中心 & 地铭中心 & 地得 - 社期观方 \\
\hline 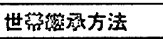 & 逶婉的 & 一括 & 段階別 \\
\hline
\end{tabular}

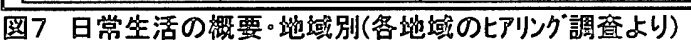

は家族や個人での楽しみに収束する。地域別では, 都市近郊Aでは 家事, 個人の遊び，社緑組織会合を中心として，地緑に関係しない 活動が多い。男性は仕事を中心とした生活，女性の親世帯は個人の 趣味を楽しんでいるが, 女性の子世帯は家事というイエ内の役割に

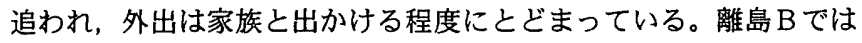
他地域と比べて全体的に集落外に出かけることそのものが少ない。 また中山間Cでは, 都市近郊 A と類似した内容であるが, 地緑組織 への会合にも多く参加している傾向がある。男女とも積極的に多種 多様な組織に参加している人が多い。

各人のイエ内における生活には，主に立場に応じた役割分担が存 在している。しかし，役割分担の仕方によっては，立場に規定され ない新たな活動への取り組みが可能になっていることが明らかとな った。C 地域にみられるように，互いの役割を明確に分担し，かつ 協力し合い, 各人の主体性を確保するといった一つのしくみは, 地 域社会の活動を促進する基盤となっていることが認められた。

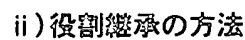

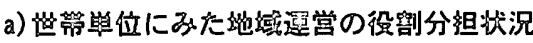

『地域社会を支えるイエ内部のしくみ】の ii ) 役割継承の方法につ いて，まず世帯別にみた活動参加状況を捉えることにより，夫婦及 び世帯間の地域運営に関する役割分担状況と特徵を明らかにする。 1 世帯を 1 サンプルとして, 男性の参加している活動内容 6 分野と, その妻 6 分野の計 12 指標を設定し, 世帯を数量化正類で得点值化し, 各世帯の得点值をクラスター分析ウォード法により B1〜B6 の 6 類 型に分頪した(図 9,10,11)。I 軸は, 十側に男女の生産組織, 一側に は男女の世代別組織が付置し, 地縁を前提とした集団であるか否か

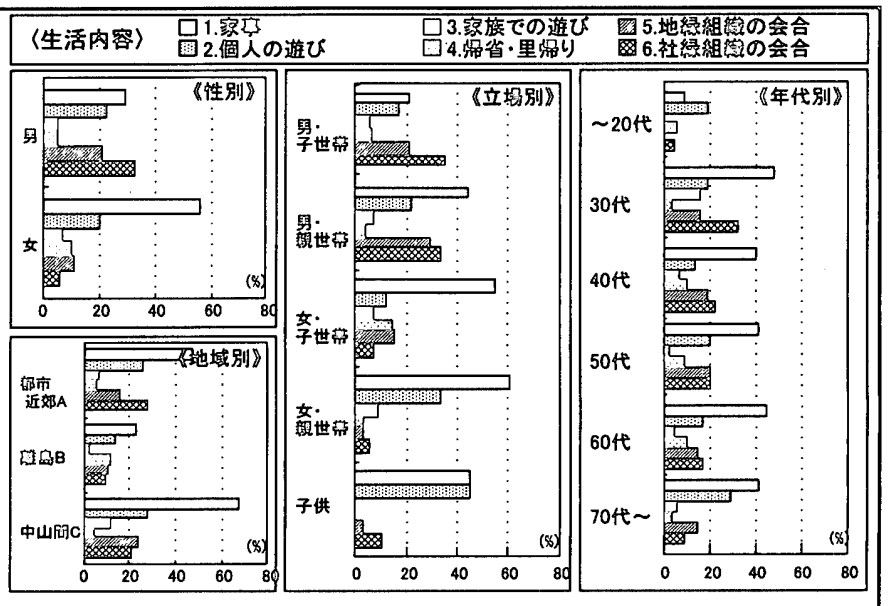

图8 篹藻外での坐活内容·屈倿別

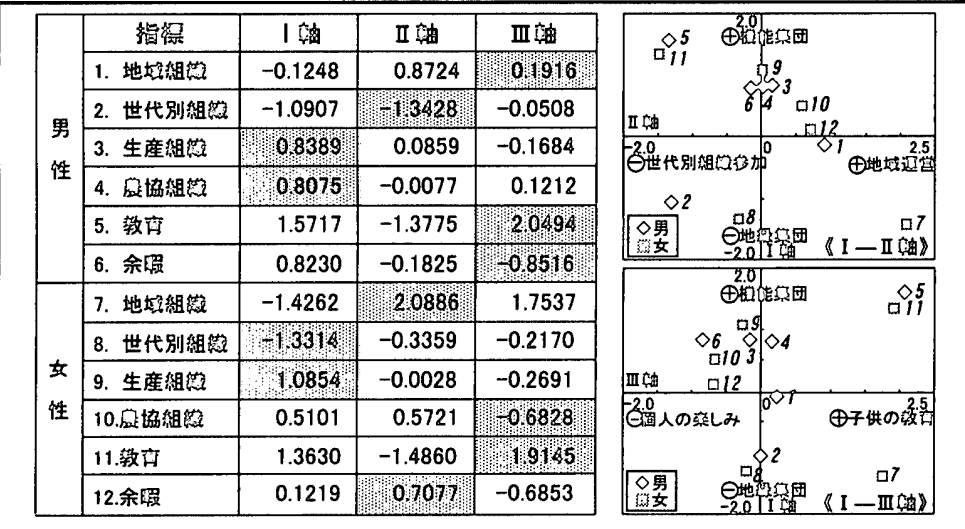

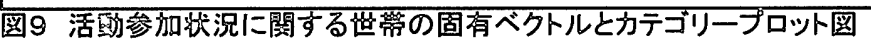

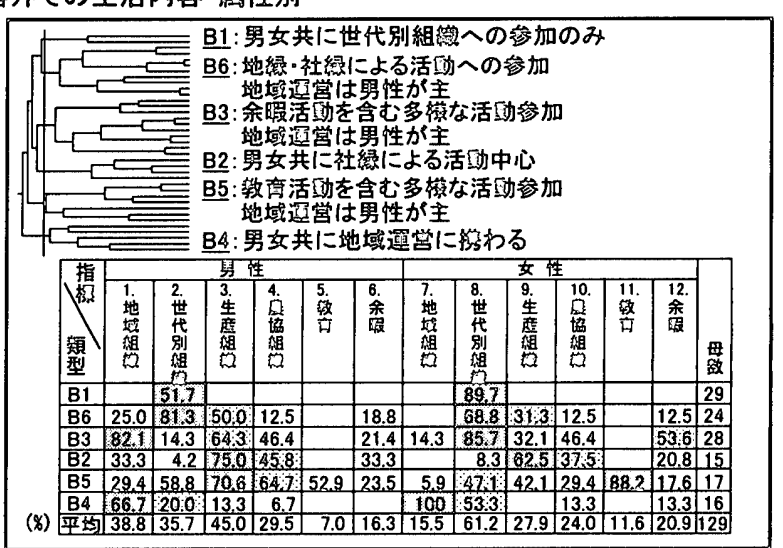

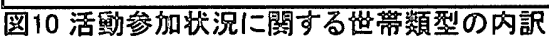


に分かれる。II 軸は十側に女性の地域組織，一側に男性の世代別組 織等が付置し，世帯として地域運営に参画しているかが捉えられる。 またIII軸では，十側に教育，一側に個人の楽しみである余暇及び女 性の農協組織等が付置する。男性の地域組織を要として,生産組織, 農協組織，余暇が付随していることが求められる。世帯類型の内訳 としては，夫婦間で活動の質が同様であるのはタイプ $\mathrm{B} 1, \mathrm{~B} 2, \mathrm{~B} 4$ 違いがみられるのはタイプ B3,B5,B6 である。前者の B4 は夫婦と もに地域運営に参画する新たな参加形態と捉えられる。また, 後者 で夫婦共に多様な活動参加をしているのは，地域運営を活動の中心 とした B3，及び教育活動にも参加している B5 である。

世帯別の特徵として，子世帯は主に社縁活動中心の B2，もしくは 地縁に関倸した活動と教育活動にも参加している B5 が多くみられ る(図 12)。また親世帯は地縁集団に拠っている B1，もしくは地域運 営中心の B3 で主に構成されている。年代別の特徵としては, 男性側 の年齢を世帯年齢としてみると 40 代から B3 が增しており，地域運 営への参加について 50 代ではその中心， 60 代になるとその他の地 縁による活動が多くなっている。また，教育活動への参加がみられ る B5 は若い世代，B3 は 50.60 代で専ら構成されている。地域別に 親子世帯間の特徵でみると，都市近郊 A は，子世帯は職能集団の B2 に多く属している。親世帯は様々な類型がみられ，現在でも地域運 営に関わっている B3，もしくは引退している B1，B6 の両者が存在 する。また核家族になると B2 の職能集団に偏るか, B6 の活動数が 少なくなる傾向がみられる。離島 $\mathrm{B}$ は, 親子世帯共に地縁による活 動が多いが, 特に親世帯の多くが隠居型のB1 に属している。また, 核家族については，男女とも地域運営に参画する B4 が多くみられ，
女性も地域社会において重要な役割を担っている。中山間Cは，親 世帯が地域運営中心の B3 に, 子世帯は教育活動への参加もみられる B5 というように，世帯間において中心となる活動内容は異なるもの の，親子世帯ともに幅広い活動参加がみられる。

このように, 活動参加状況は夫婦間・親子間における特徵がみら れ，地域運営の担い手層に関して立場に規定された地域固有のしく みがあることが示された。依然として地域運営は男性中心であるこ とが多いが，女性にも離島 B の核家族や中山間 C の桩大家族にみら れたことは，新たな役割分担の方法と捉えられる。

\section{b)イエ単位にみた役割継承の方法}

まず，ヒアリング調査から得られた各地域の役割継承の方法につ いて概要と特徽を示す(図 13)。親世帯から子世帯への世帯主の権利 の渡し方から，(1)親世帯主導の連続的な継承，(2)子世帯中心の一括 継承，(3)親子分担による段階別の分割継承の 3 タイプが提えられた。

(1)親世帯主導の連続的な継承は農村での一般的な形態であるが, 調査事例の中では都市近郊Aでみられ，世帯継承は各家の事情に応 じて, 親世帯から子世帯へ各種権利が連続的に渡されるタイプであ る。よって, 親世帯が子世帯をイエの代表として育成していく期間 は自ずと長くなり，親子を中心とする縦のつながりを軸とした継承 がなされるしくみとなる。(2)子世帯中心の一括継承は，特に離島 $\mathrm{B}$ の「世帯渡し」と呼ばれる地域独特の隠居制度にみられた。子世帯主 の結婚後まもなく親世帯から各種権利を一度に渡され，同時に親は 離れに移り，母屋を子世帯に譲るといった慣習がみられる。そこに は，子世帯主をイエの代表として地域社会に送りだし，短期間のう ちに一戸前に育て上げるしくみができている。(3)親子分担による段
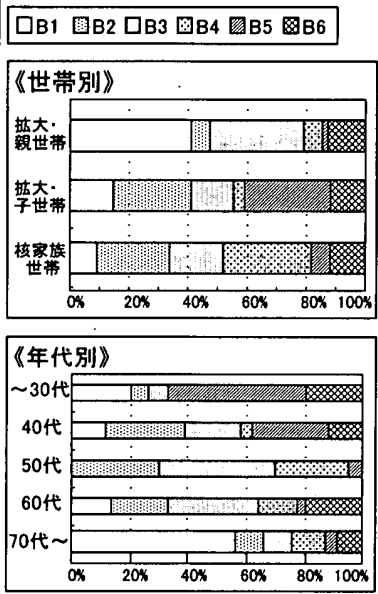

\section{《地域別》}

$=$ 都市近郊 $A=$

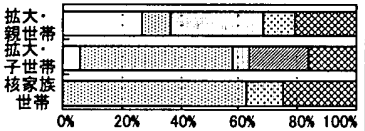

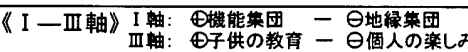

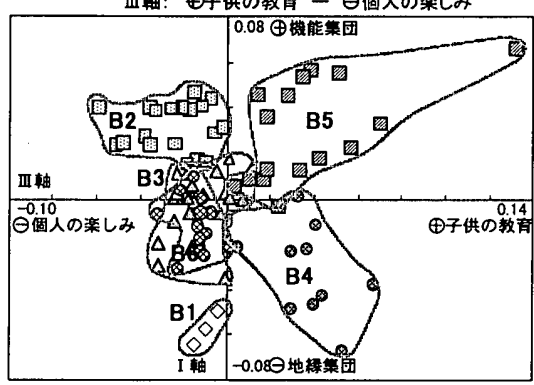

図11 世帯のサンプルプロット及び類型図

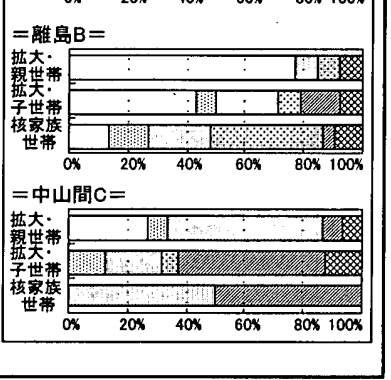

図12 世帯類型の属性別割合

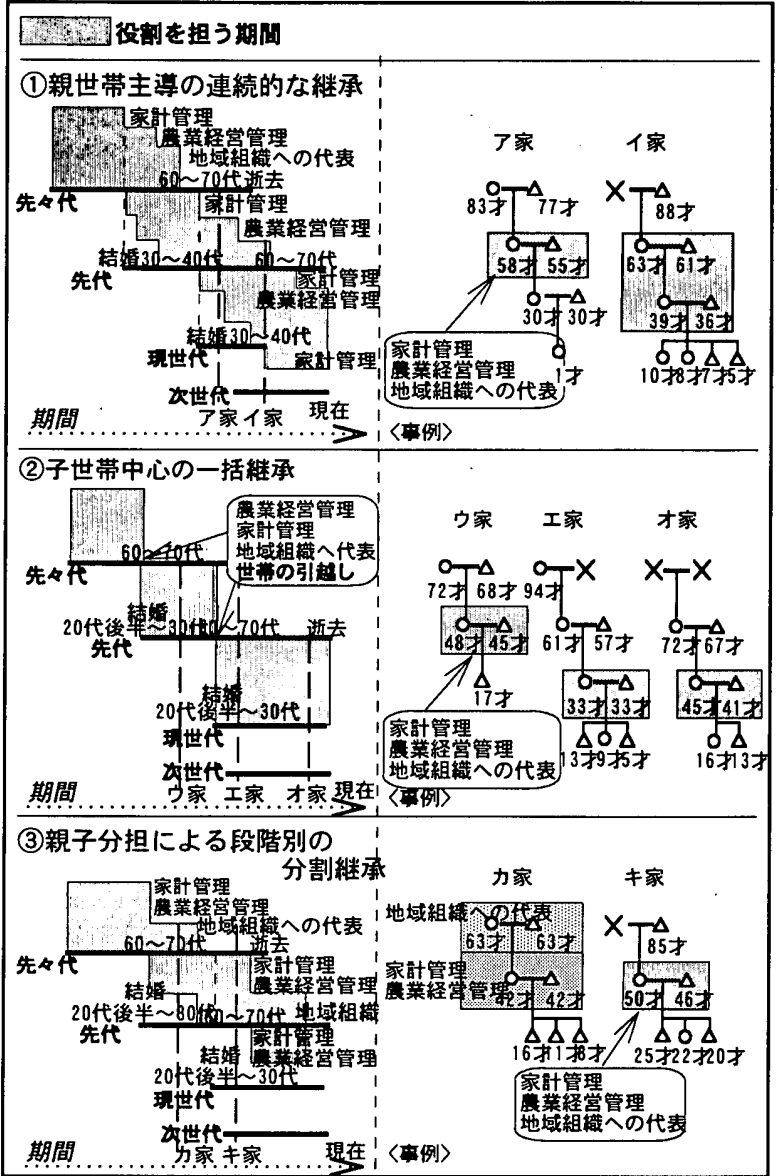

図13 役割継承の方法 


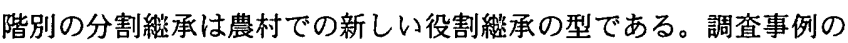
中では中山間Cでみられ，子世帯は若くして農業経営・家計管理を 任され，数年後に世帯主・地域組織参加代表の権利が渡されるとい う段階別に継承されるタイプである。これは，イエ内の役割は子世 帯中心，イ工外の地域運営は親世帯中心といった明確な役割分担が なされることになる。また女性も男性と対等に農業経営に参画して いる世带がみられた。

次に地域社会におけるイエを単位とした活動参加状況を把握する ことにより，イエ内の世帯間における地域運営に関する役割分担状 況とその特徵を明らかにし, 地域別で捉えることにより, 各地域で 得られた役割継承の方法と照らし合わせて考察する。4 章ii）a）にお ける分析結果より図 11 としてプロットされた各世帯について, 同扗 大家族内の親世帯と子世帯との点を結び，イエとしての活動参加状 況を線分で表す(図 14)。

事例地の都市近郊 A は子世帯の多くが機能集団に偏っており，親 世帯が地域㖶営を担う, もしくは世代別組織参加程度に止まるとい う大きく2つの傾向がみられる。役割継承の方法が1)親世帯主導の 連続的継承により，従来型のイエを単位とした社会参画になること から, 個人・世帯の主体性が確保されにくいため, 主体的な活動参 加はへの広がりは少ない傾向にある。ただし，親子ともに主体的な 活動参加をしているイエもみられ，新たな親子関係と捉えられる。 離島 B は親・子世帯ともに地緑集団に偏っており，地域運営の主な 担い手は子世帯となっている。これはイエ内部の役割の(2)一括継承 により, 子世帯が $20 \cdot 30$ 代の世帯渡しをいまだ行っていないイエ, もしくは摜習のみられないイエと，世帯渡し後の親世帯が隠居し子
世帯が地域運営に参画しているイエとして捉えられた。個人の主体 的な活動参加が少ないのは, 子世帯が担うイエとしての役割の大き さにより，個人単位の活動に制限があると考えられる。また核家族 の場合は，親世帯の年代に近くなっても地域運営の役割は引き続き 果たしており，女性の参画もみられ，地域社会を支える一員として 役割を担い続けている。中山間 C は特に II 軸に関して親・子世帯が 対称に付置しているイエが多い。親世帯が地域運営の担い手, 子世 帯は教育活動を含めた樻極的な活動参加がみられるイエは(3)分割縋 承の一段階目である親世帯が地域運営, 子世帯が諸活動への主体的 な参加がみられるイエと捉えられる。また親世帯が世代別組織程度 の参加となり, 子世帯が地域運営を主とした活動を行っているイエ もみられ，離島 $\mathrm{B}$ で示された親子関係に同質である。これは(3)分割 繼承の二段階目である親世帯が高齢で隱居し, 子世帯がイエの代表 となっているイエと捉えられる。世帯間の明確な役割分担と過度な 負担がかからない繼承方法により, 個人・世帯の主体性が確保され た活動参加が図られていると考えられる。

このように, 親子間, 男女間の比較で捉えたイエ内における活動 参加状況と役割継承の方法とを照らし合わせることにより, 地域に 規定されたイエにおける縋承方法が求められた。親世帯から子世帯 への世帯主の権利の渡し方について, 継承の時期・内容及び親子世 帯間の関係から 3 つのタイプが得られ, 地域社会におけるイエの代 表としての役割が，しくみを基盤として年代や立場に応じて縋承さ れることが求められた。中山間Cで多くみられた世帯間における明 確な役割分担がなされた継承方法は，イエとしての役割を褁たしな がら, かつ個々人が地域社会における多種多様な活動に参加してお

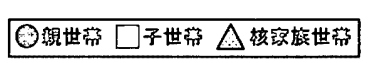

=部市近部 $A=$

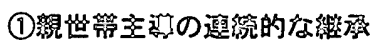

$(1-11$ 简 $)$

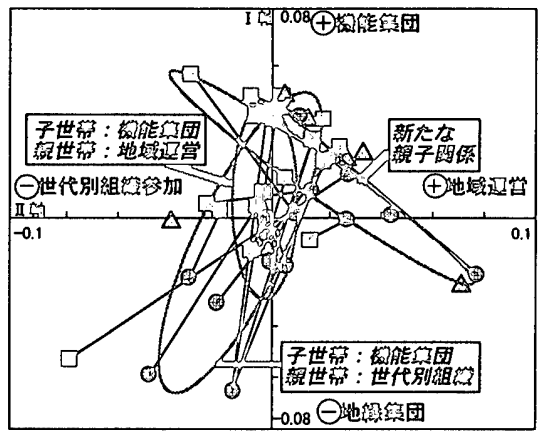

$\langle 1-\|$ 㩂 $\rangle$

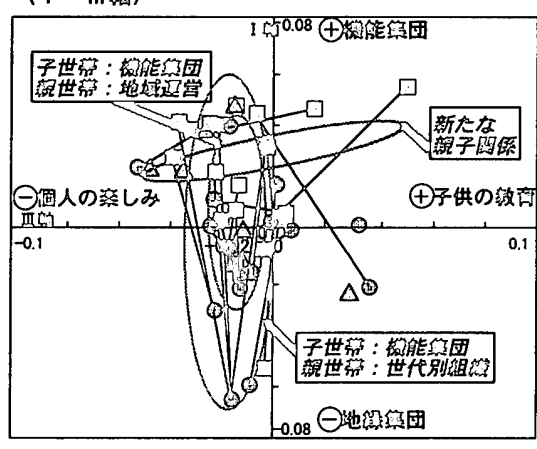

$=$ 酸盘 $\mathrm{B}=$

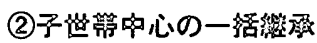

$\langle 1-\|$ 新〉
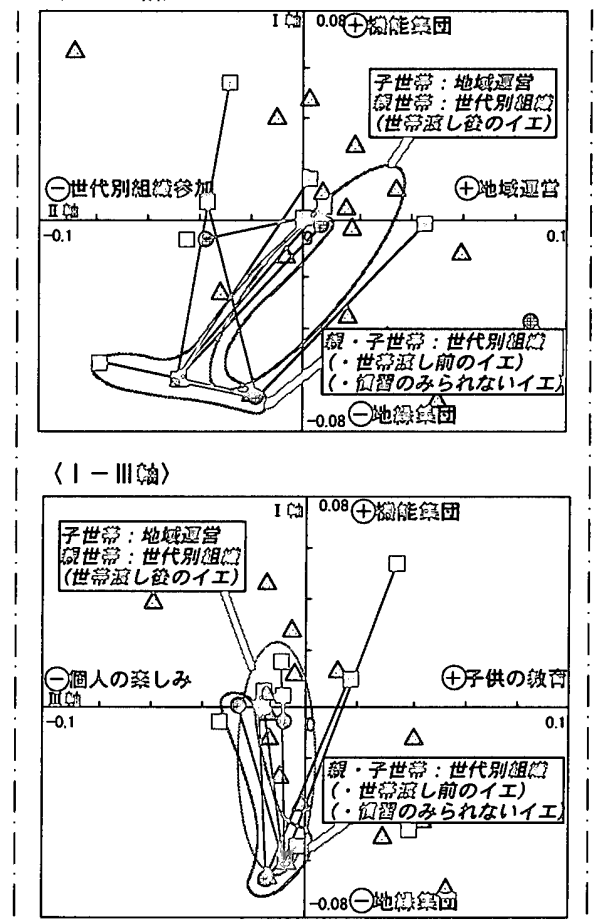

$=$ 中山間 $\mathrm{C}=$

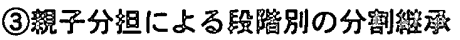

$\langle 1-\|$ 辋 $\rangle$

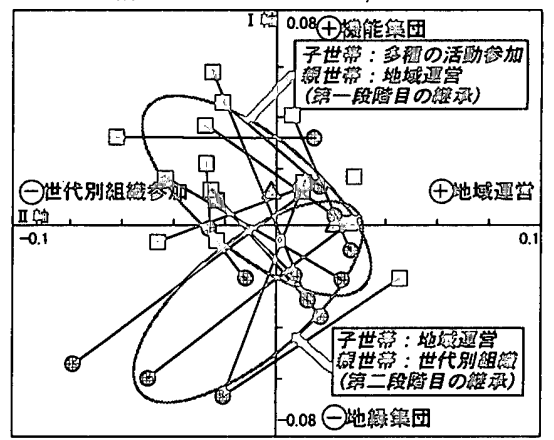

$\langle 1-\|||-0)$

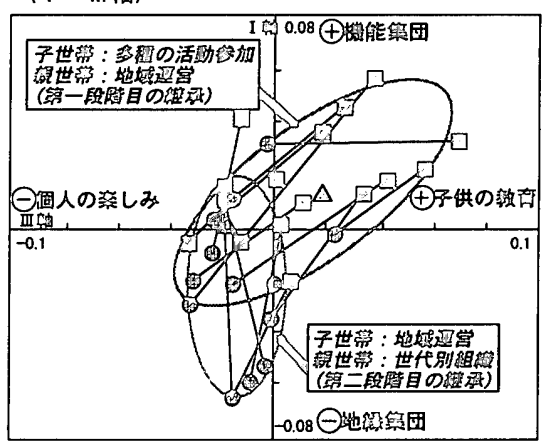

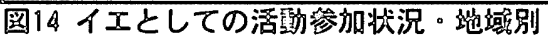


り，地域社会の活動の活性化及び社会の維持・継承を促すと考えら れる。他方，地域に規定されず，親子ともに積極的な活動を行って いるイエもみられ，新たな親子関係として捉えられる。

イエ内部の役割分担及び役割継承の方法から，個人，世帯，イエ との地域社会との関係が明らかとなった（図 15）。世帯間に依存関 係がみられ役割継承の方法が(1)連続的な場合，親世帯主導であるこ とから (a)イエ中心の従来型の社会参画となり，個人・世帯の主体性 は制限される。また, 各世帯の主体性を確保した(2)一括的な役割継 承は，(b)世帯中心の新たな社会参画の方法と捉えられるが, 役割負 担の度合によっては個人の主体性が制限され得る。さらに，新たな 親子関係として(3)段階別の役割継承については，個人・世帯の明確 な役割分担と協力関係により互いの主体性を確保し，かつ地域社会 においてイエの役割を果たし，イエと地域社会双方の維持・継承を 図っていることが求められた。

\section{5. 地域社会に存在するしくみの意義と今後の地域社会形成}

地域社会に存在するしくみを通じて得られた経験が, 各人の価值 観にどのような影響を与えているのかを把握する。

\section{i）地域社会において協力していく大切さを実感した時期と機会}

第一に，地域社会において協力していく大切さ(以下，協調性）を 実感した $\{$ 時期 $\}$ と\{機会\}を個人単位で把握し，地域社会のしくみの意 義を示す。

まず協調性を実感した\{時期\}について, 全体として[結婚]後が多く 挙げられているが，[就職]前の若い世代から実感している人も少な くない(図 16)。性別にみると，女性の方が概して[結婚]による環境 変化が大きく, 新たな社会に適応するためにも意識を高める重要な
時点となっている一方, 男性は[結婚]後も同地域で暮らす場合が多 いことから，[就職]前から自分の地域に対する関心を持ち得ている と捉えられる。立場別では，特に親子間の大きな差はみられない。 年代別の特徵としても，20 代までは，いまだ協調性の実感を得てい ない人がみられるものの, 30 代以降は[結婚]を機に得ており，60 代 以降に[就職]前を挙げている人がやや增している程度である。地域 別にみると, 都市近郊 $\mathrm{A}$ は主に[結婚]を機に, 中山間 $\mathrm{C}$ は[結婚]後

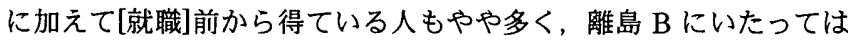
[結婚]と[就職]前から得ている人の割合が同程度に高くなっている。 次に協調性を実感した $\{$ 機会\}については，全体として地域のなん らかの会で[仕事]を請け負うこと, 会の重要な役目である[役職]に就

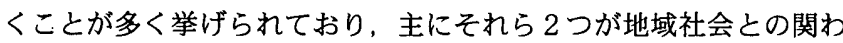
りを持つ重要な機会となっている（図 17）。また性別に加えて立場 別の特徵をみると，子世帯に比べて親世帯の男性は会に[代役]とし て参加したことを挙げており，[代役]という経験も重要な機会であ つたことが分かる。同様に親世帯の女性は[役職]経験も挙げており， 加㛔により女性であっても会のまとめ役になる機会がやや增すとい える。年代別では，30 代は会の[一員]や[仕事]を請け負った機会を 挙げているが，40 代以降になると実際に[役職]経験も増えてくるこ とから，それに対する評価が表れている。地域別にみると，都市近 郊 A は, [仕事]や[役職]を同程度に挙げている。これは役割継承の 特徵にみられるように，イエの代表としての責任を親世帯主に任せ ている一面もあることが，その実感をやや遅らせていると考えられ る。離島 $\mathrm{B}$ は，会の[仕事]を請け負うことから協調性を得ている。 地域独特の世帯渡しによって, 若くからイエの代表としての貴任感

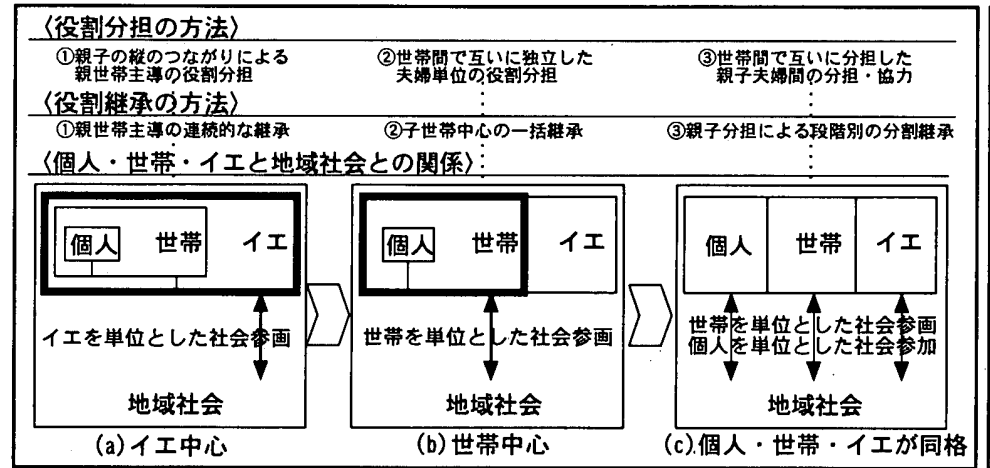

图15 個人·世带・イエと地域社会との関係に関する概念図

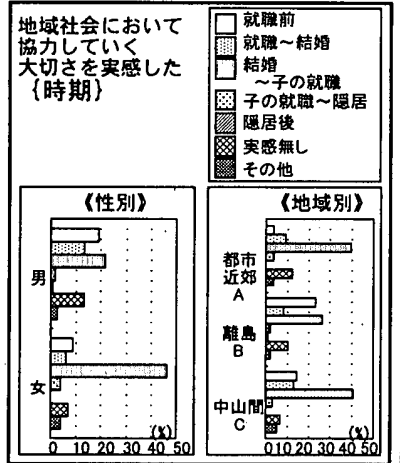

図16 協調性を学んだ [時期\}

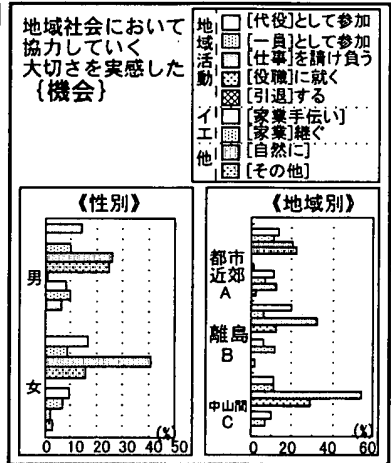

図17 協調性を学んだ \{機会\}

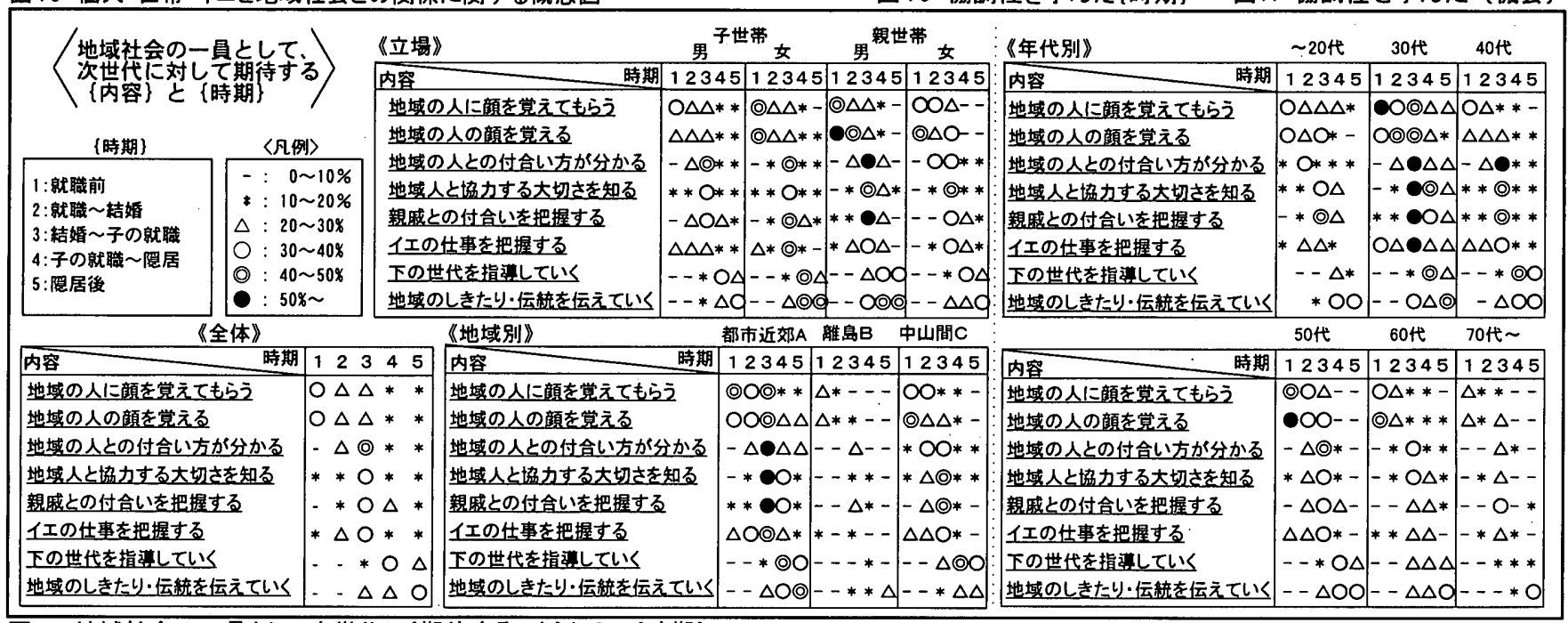

図18 地域社会の一員として次世代に[期待すること]とその[時期] 


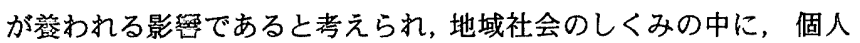
とイエとが内包されていると捉えられる。中山間 C は, 会の[仕事] を詣け負う頃には協調性を実感し, 意識も高い。幅広い活動参加に より多くの経跧を重ねる中で, 互いに地域社会を支え合う関倸が作 られてきたと考えられる。

このように, 地域社会のしくみを基盤として, 加莑や[就職]・[結 婚]という人生の節目に応じて, また地域社会の[仕事]・[役職]を担 うといった経験から, 地域社会における協調性を学び, 地域社会の 一員としての役割認識を持つことが明らかとなった。

ii ) 绝坛往会の一貣として次爫代に期待すること

第二に, 地域社会の一員として, 各世代の各時期においてどの程 度のことが必要か, \{期待すること\}とその\{時期\}に対する考えについ て各人の経鈳則を背景として捉え, 地域社会のしくみの意義と今後 の地域社会形成の方向性を探る。

全体像として, [結婚]前までに顔を覚え, また覚えてもらい, [結 婚後，人とのつきあい・協力や親成つきあい。イエの仕事を把握す る。[子の就職]後は次世代を指導し伝統を伝え, [隀居]後は伝統を伝 えていくという一連の流れが把握できる(図 20)。この傾向は男女共 に同様にみられるが, 男性はイエの仕事を把握することに対して[就 職]前から必要であるとの考えがある。立場別では, 特に親子世帯間 の違いはあまりみられない。また年代別でも，30～50 代は地域の人 の顔を把握することに対して, [就職]前から[結婚]後までの期間を挙 げているが, 60 代以降は[就職]前にやや偏っており, 若年層の方が 地域と関わりを持つことを急いでいない傾向がみられる程度である。 [結婚]後から[子の就職]までの期間にあたる 30〜50 代については, 地域社会・イエの担い手である当事者であり，実際それらに対する 期待を自身が挙げていることは，イエ・地域社会における役割の必 要性を実感していると捉えられる。地域別にみると, 都市近郊 A は, 地域のしきたり・伝統を伝えていくことには大きな関心がみられる ものの, [就職]前までは地域社会との関わりに対する期待が低くな っている。このことは若世代の担い手としての認識を遅らせる要因 の一つと考えられる。離島 $\mathrm{B}$ は総じて期待が低い。特に, 地域への 協力, イエの仕事の把握, 後猆指導に対する期待はあまりみられず, 時期については, [就職]前, [結婚]後, [隠居]後の 3 つにのみ集中し ている。これは，地域社会が若い世代を育てていくといったしくみ があり，いわば日常生活が地域社会に溶け込んでいるため，特に意 識せずとも必然的に役割を果たしていることによると考えられる。 中山間 $\mathrm{C}$ は, [就職]をきっかけとして地域とのつきあいを求めてお り, 後澋指導に対しても早い時期から関心を持っている。役割継承 の特徵からいえば，親子世帯間で役割を分担し，それぞれに任せる ものの, 地域社会との関わりは長く大切にするべきだという認識を 持っていると捉えられる。

以上のことから, 個々人が地域社会における役割内容とそれを果 たすべき時期を認知しており, 個人の価值観とイエ・地域社会のし くみは密接に関係し，社会形成において各々切り離せないものとな っていることが求められた。地域社会のしくみを通じて, 若い世代 が地域社会運営の担い手として育成され，各人が社会への関心を高 めていくことは, 地域社会の維持・継承を促す人材かつ土台を作り 出していると捉えられる。

\section{6.まと的}

以下に，イエ・地域社会の維持・䋖承の内容と方法をまとめる。 1）個人の地域社会への関わり方は性別に規定された男女の役割型 が示され, また経験則から活動内容が 50 代までは役割遂行型, それ 以降は余暇充実型という年代に規定された参加形態が明らかとなり， 地域社会運営の担い手として役割を果たす時期は $50 \cdot 60$ 代であるこ とが求められた。従来の男性主導の地域運営に加え, 女性の社会参 画がみられたことは, 新たな地域社会運営の方法として捉えられる。 2）イエ内部の役割分担の方法は，主にイエ内の立場に規定されるこ とが求められた。従来のイエを単位とした社会参画から, 新たに親 子。夫婦間の役割分担，協力，支援による世带単位の参画が捉えら れ，個人・世帯の主体性が確保されていることが明らかとなった。 これは個人・世帯の幅広い社会参加を促し, 地域社会における活動 の活性化が図られると考えられる。

3）イ工内部の役割䌭承の方法に, (1)親主導の連続的綀承, (2)子世帯 中心の一括継承, (3)親子分担による段階別の分割継承の 3 タイプが 事例地より求められ，イエ内の役割が立場に応じて縋承され，かつ 地域固有の繼承方法が明らかとなった。従来型の(1)連続的繼承によ るイエ単位の社会参画に加えて，(2)一括䌡承では世帯中心の社会参 画及び課題として個人の主体性の制限が捉えられ，(3)分割縋承にお いて世帯単位の社会参画之個人・世帯の主体性が確保された新たな 継承方法が求められた。イ工内の世帯継承により地域社会における イエの代表を育成することは，地域社会の繼承にも重要である。

4）地域社会のしくみを通じて, 地域社会における協調性や役割を学 んでいくことが明らかとなった。若い世代から社会参加ができ，各 人が立場に相応した社会における役割内容を認知し果たしていける しくみは，イエ・地域社会の維持・継承の基盤となる。

5)地域社会の運営方法において、個人が育成され次世代に役割が繼 承されていくしくみ、並びにイエ内部の役割分担及び役割綎承の方 法において、個人・世帯の主体性が確保され、かつ地域社会におけ るイエとしての役割が継承されていく新たなしくみ、これら地域社 会とイエ双方のしくみが連動することは、今後の地域社会の維持・ 継承において有用である。

注 1)「イエ」:ここで捉えているイエとは,農村社会学に準じ「鈴条慗太郎著 作集 I 」で記述されている「…家における社会生活の原理は, …中略…家族内 における家長を中心とするそれぞれの位座の整序にその骨格を示している。 そして個々の位座間に精密な規篹が存している。…」に基づく。 [参考文献]

1)鈴太榮太郎:鈴木啉太郎著作集 IJ,未来社, 1968.4 2)福武直:日本村落の社会構造,東京大学出版会, 1969 3)余田博通,松原治郎:農村社会学,川息書店, 1969

4)蓮見音彦編:社会学講座第 4 巻農村社会学,東京大学出版会 1973 5)有賀當左衛門:村の生活組織, 未来社, 1976

6)捠田陽太郎，宮崎礼子，矢口光子:対談・農村生活を考える,全国新聞情報農業 協同組合連合会, 1979

7)蓮見音彦,奥田道大編:地域社会論 住民生活と地域組織,有斐閣, 1980

8)福武直:日本の農村(第二版), 東京大学出版会, 1981

9)安達生恒:現代農民の生活之行動,日本経济評論社, 1981

10)日本農村生活研究会東北支部編:むらと農村生活の新展開,明文書房, 1981

11)長谷川昭彦:典村の家族と地域社会 その論理と課題,御茶の水書房, 1986

12)塚本哲人編著:現代農村における「いえ」と「むら」,未来社, 1990

13)高橋明善:農村社会の变貌亡農民意識,東京大学出版会, 1992

14)山猗義人,後藤春彦,村上佳代:島民生活の体系的把握に上る子宝島の生活 睘境に関する考察 〜離島の人口定着と地域維持に関する研究, 日本建築学 会計画系論文報告集 No.500,p.153, 1997.10

15)村上佳代,後藤春彦,角田理江:離島の生活環境計画と振興方策のあり方に 関する研究 〜奄美群島振興特別措置法と瀬戸内町集落の人口動熊・生活圈 域に着目して，日本建等学会計画系論文報告集 No.513,p.175, 1998.11 